\title{
Rewriting Cultural Paradigms: Translating the Roman Missal in Congo-Zaire
}

\author{
RESHMA ANN ROLLIN
}

\begin{abstract}
The Missale Romanum is the book which contains the prayers and rituals used for the Mass, the most important ritualistic celebration of the Catholic Church. Though the Vatican approves only those regional translations of the Missale Romanum which adhere to its prescribed norms, the translation in the Zaire-Congo region known as The Roman Missal for the Dioceses of Zaire is an anomaly since it goes beyond these norms by including cultural elements peculiar to the region, but yet managed to get its approval by the Vatican. The Latin Missale Romanum was thus translated using culture specific parameters in the Congo-Zaire region of Africa. This article seeks to examine this unique translation- its origins and the way it deviated from its source text.
\end{abstract}

Keywords: Translation, Catholic Church, Roman Missal, Congo-Zaire, Enculturation.

\section{Introduction}

The Catholic Church is an influx of various cultures; varied cultures intermingle and coexist within it. Though the Vatican has tried to maintain uniformity in terms of the structure of the liturgical celebrations in the Latin Church ${ }^{1}$, especially in the

\footnotetext{
${ }^{1}$ The Catholic Church is divided into two- the Western Church or the Latin Church (which forms the majority of the members of the Catholic Church) and the Eastern Catholic Churches or the Oriental Catholic Churches which consists of 23 other individual Rites. The Western Church Mass is similar to the Papal Mass and is bound to be regulated by Papal authority and norms while the individual Rites in the Eastern Catholic Churches are not
} 
celebration of the Mass ${ }^{2}$ (the text of which is) contained in the Missale Romanum ${ }^{3}$, by issuing norms from time to time, the culture of the particular area in which it is implemented is always reflected in certain parts of the Mass. It is in such a scenario that the Missel Romain pour les Dioceses du Zaire, the Missal for the Zaire Usage of the Roman Rite (hereafter referred to as the "Zaire Usage") came into existence in 1988. The Zaire Usage can be regarded as the product of modernism, enculturation and the richness of Congolese culture (Zaire is now known as 'Democratic Republic of Congo'4). It deviated radically from the traditional Latin Missale Romanum, which was the source text for translation to other languages, even in terms of the order of the rituals or the nature of the prayers. This is clearly a situation where the translation of the Roman Missal for the region of Zaire can be equated to translating the culture of Zaire. The paradox is that the vernacular version of

regulated by the above mentioned norms. This article discusses the text of the Mass in the Latin Catholic Church.

${ }^{2}$ Chief ritualistic celebration of the Catholic Church; considered to be a reenactment of the Last Supper which Christ had with his disciples. It consists of five parts: Introductory Rites [Entrance Procession, Penitential rite (prayers asking for forgiveness from sins) and Gloria, (a hymn praising God)], Liturgy of the Word (Readings from the Bible, Sermon, the Creed, a summation of Catholic faith, and Prayer of the Faithful, petitions of the Church and the laity); Liturgy of the Eucharist (Offertory, the people bring their individual gifts or offerings, mostly in-kind, Preparation of the Gifts, priest prepares the bread and wine to be offered) and Eucharistic Prayer, prayers offering thanksgiving and praise), Communion Rite (bread and wine, considered to be "the body and blood of Christ" is given to the faithful) and Concluding Rite.

${ }^{3}$ The prayers and the instructions for celebrating the Mass are contained in the Missale Romanum, which is in Latin, the official language of the Catholic Church.

${ }^{4}$ Since these changes in translation were made prior to Zaire becoming the Democratic Republic of Congo, I will also be referring to the region as Zaire. 
the Missale Romanum used in a region had to conform to the norms prescribed by the Vatican ${ }^{5}$ from time to time, while the Vatican's stringent laws on granting approval to a regional version of the Missale Romanum was overlooked in such newly-evangelised African dioceses, which carry with them the richness and depth of their cultural heritage. This paper attempts to look into the unique process of translation and reinterpretation of the Catholic Mass in an African context, specifically in the region of Zaire-Congo, by considering the special case of the Zaire Usage.

The Mass is the central pivot around which the life of the Catholic community all around the world revolves. All the readings, prayers, chants and guidelines used in the Mass for the Latin Catholic Rite ${ }^{6}$ have been compiled in a book-form, which came to be known as the Missale Romanum. Originally written in Latin, the Missale Romanum didn't exist as such in the beginning. Various parts have been added and deleted at various points and in accordance with different instructions ${ }^{7}$ which have been promulgated over time by the Vatican. The prayers, responses and instructions in this book have evolved over centuries and Christian theologians have traced the history of the prayers, right from the Last Supper. The Mass was in Latin, so was the text; Latin being the official language of the Church. This was the case even in the newlyevangelised regions as well. Later, while trying to follow the policy of "enculturation" of the Second Vatican Council ${ }^{8}$, the

\footnotetext{
${ }^{5}$ The Vatican is responsible for formulating the norms for translating the Missale Romanum.

${ }^{6}$ Refer 1.

${ }^{7}$ Refers to the norms mentioned in 5 .

${ }^{8}$ The Second Vatican Council also known as Vatican II (1962-1965) was convened by Pope John XXIII and is significant in this context because the Catholic Church began its stand of enculturation after the discussions which came up from this Council.
} 
Mass was translated into English and then into the respective vernacular ${ }^{9}$ tongues.

\section{Tracing the Need for an "Enculturated" Usage}

The New Catholic Encyclopaedia defines enculturation as “... the presentation and re-expression of the Gospel in forms and terms proper to culture. It results in the creative reinterpretation of both, without being unfaithful to either" (2003). The notion of enculturation existed right from the beginning of the spread of Catholicism; some theologians regard the speech of St. Paul to the Gentiles ${ }^{10}$ as the first effort at enculturation. Clauses 37-40 of the Church Document, Sacrosanctum Concilium $^{11}$ sums up the essence of enculturation in translation:

... the Church has no wish to impose uniformity in matters which do not implicate the faith or the good of the whole community...Provisions shall also be made, when revising the liturgical books, for legitimate variations and adaptations to different groups, regions and peoples, especially in mission lands, provided that the substantial unity of the Roman Rite is preserved; and this shall be borne in mind when drawing up the rites and devising rubrics (Sancrosanctum Concilium 1964: sec. 37-38).

In short, even while exhorting that it did not wish to impose "uniformity", the Catholic Church was giving the "mission lands" a kind of autonomy to translate and produce a Missal

9 The choice of vernacular languages to which the Missal could be translated rested upon the recommendation of the region's bishop.

${ }^{10}$ Refer Acts 17:22-31.

11 One among the four significant documents produced by the Second Vatican Council. It aimed at improving the participation of lay people within the Catholic Church and more importantly, stressed on the need for translation of the Missale Romanum into the native languages. 
which retained the basic structure of a traditional Mass but was free in other ways to include cultural elements. It is to be noted that these "mission lands" refer to newly-evangelised places where Catholicism has not been in practice for long.

Formally, the idea of enculturation was an offspring of the deliberations following the Second Vatican Council. The Mass of the Pre-Vatican II era gave more focus to the priest and the laity $^{12}$ was more or less ignored. There were not many responses for the laity, who stood passive for the Mass, while the priest performed the rituals and said the prayers. What dominated in these rituals was the person of the priest, who was considered to be the 'representative' of Christ.

The hermeneutics of the Second Vatican Council deconstructed the Mass by seeing it as a space where the laity too could actively participate in their own right, being designated as the 'People of God'13. The interaction is not just of words, but also of symbols, which are both linguistic and cultural (Kangas 2013). The Council was a historical landmark which increased the participation of the laity, thus, in a way, making the Mass more 'interactive, ${ }^{14}$. The Second Vatican Council admitted the need and also the existence of diversity within the Church following the spread of the Catholic faith through evangelization and hence took the significant step of encouraging the translation of the text of the Mass contained in the Missale Romanum into English and the vernacular languages, with the primary aim of making the texts accessible

${ }^{12}$ Lay people, members of the Catholic Church other than the clergy.

13 This was one among the many phrases used to designate the relationship between God and the People in the Eucharistic Prayer of the Roman Missal. 14 The number of responses for the laity was increased when compared to complete passivity or inactivity in the Mass celebrated before the Second Vatican Council. 
to the local communities and adapting some parts of their tradition into the Missal.

Evangelization had created a number of converts in Zaire; they accepted their Catholic faith, but certain elements of their previous tribal religion had a profound impact on them. Alex Chima recalls an incident where a religious teacher from Africa told him that the laity went to a pagan ${ }^{15}$ rain sacrifice after attending Mass. He comments on the incident thus: "The Mass did not seem to them to be relevant to their real needs. If the Mass does not seem relevant to human needs like sickness, drought, epidemics, time of childbirth and death, then there is something radically wrong about the way our liturgy is celebrated" (Chima 1984: 282). Chima here is pointing to a significant way of thinking of the tribals who would rather call a religious priest than a doctor in times of sickness and this has been pointed out by many missionaries who worked in the region. It was as if the Mass for the tribals was complementary in the sense that they attended mass as their first priority and then went for the rain sacrifice as they believed in praying for rain or protection from the elements; this can mean that they wanted to include certain elements of their erstwhile faith into their new-found belief. This explains the need for a Mass which catered to the needs of the people and which was also closer to their tradition and culture. Chima explains why an "enculturated" Missal was the need of the hour, if the people had to complement their new-found faith with their previous faith, to feel a kind of completion. These views which were expressed in his article titled "Africanising the Liturgy- Where are we Twenty Years after Vatican II!" published in 1984, would soon find a kind of answer in the Zaire Usage (1988). Thus, prayers for special intentions began to be included in

${ }^{15}$ Here, Chima is referring to tribal traditions. 
Eucharistic prayer ${ }^{16}$ of the Mass at a later stage, according to the needs of the community. It could be for a good harvest, favourable weather or for peace.

The usual question of fidelity to the Latin source text is brushed aside here; what matters is whether the translation is faithful in catering to the local culture of Zaire. The words used in the translation did not seem to create desired effect on the natives. The influence of the Belgian missionaries found its way into the translation of the Missale Romanum as well, as it tried to find equivalents in the target Lingala ${ }^{17}$ language and failed to create an impact.

To cater to the spiritual needs of the people, a sense-to-sense translation along with the addition of cultural elements was necessary, which is what the Zaire Usage did. It is remarkable that this concern is what sets apart the Zaire usage from the other vernacular translations of the Missale Romanum around the world.

\section{Historical Background}

The Zaire Usage did not come into existence all of a sudden; it did have its precursors in the Mass of the Savanes in Upper Volta and the Mass of the Piroguieres, both of which came into being in 1956 (Chase 2013: 30). Sanon comments on the evolution of these Masses thus: "The former adapted the Latin language and Gregorian melody to the rhythm of Volta drums" (Sanon 1983: 63). Foster mentions the composition of the Missa Luba (1958), by a Belgian priest, Guido Haazen (Foster 2005: 1-6). The Ndzon-Melen Mass (1958-1969), which evolved in Cameroon, was another inspiration for the development of the Zaire usage. Chase emphasized on the other endeavours to improve the African Eucharistic prayers:

\footnotetext{
${ }^{16}$ Refer 2 .

${ }^{17}$ The lingua franca of Zaire-Congo, a Bantu language.
} 
All-African Eucharistic Prayer (1970), Three More African Eucharistic Prayers (1973 - for Kenya, Tanzania and Uganda) and the Igbo Eucharistic Prayer (1980) (Chase 2013: 30).

The process of enculturation gained momentum in general within the African Catholic Church with the promulgation of the Rites of Christian Initiation (1974) which encouraged local Bishops to incorporate cultural elements while adapting initiation rites. Though this was an indirect step, it certainly echoed the general trend of enculturation within the Church which was expanding in the Mission countries. Tony Barrett in his book titled Incarnating the Church in Turkana mentions the complete enculturation of the practices of the Church of Turkana during the 1970s and this has also served as a stimulus for the formation of the Zaire Usage. Meanwhile, the Vatican had started clamping down on the liberties of vernacular translations with instructions like Liturgicae instaurationis (1970) and Eucharisiae participationem (1973) which imposed restrictions on the way the prayers of the Mass could be composed and also on giving approval for newlycomposed prayers.

The first step in the formation of the Zaire Usage began in Belgium; Zaire being a Belgian Colony then. The undercurrents of the liturgical movement were felt in Zaire too: "...the liturgical movement, which reached its peak after World War II, saw the monastery of Mont-César in Belgium as its centre stage. The impact of Mont-César on the Belgian church was not lost on the Belgian colony of Congo-Zaire" (Gibellini 1994: 97). The role of the Belgian missionaries who brought these waves of change to Zaire was also remarkable. But these missionaries failed to inculcate the true spirit of Zaire into the Mass and this led the Bishops of Zaire complain that the "...missionary liturgy was alien to Africa" (Chase 2013: 31). This resulted in the formation of a liturgical 
Rewriting Cultural Paradigms:...

commission (1969), to formulate a Mass which mirrored the culture of Zaire. This Mass was followed on a trial basis and in 1988; the Missel Romainpour les Dioceses du Zaire or the Zaire Usage was finally approved, with all its 'traditional elements'.

\section{Translating the Missal, Translating Culture}

The primary concern as far as the initial translations were concerned was, as Lynne Long aptly points out, was to make the texts available in vernaculars and hence initially the translation was done without giving much importance to the "how" of translating the text. But new translations are made after the canon is consolidated after much thought and deliberations. This is followed by "analysis and justification of translation methodology" (Long 2013: 464). As far as the Catholic Church is concerned, Long observes that "the function of the translation is perceived above all as preservation of the original" (465). The translator of a liturgical text would be looking for a translation which does not omit, modify or add anything to the existing text; creativity is always out of the question.

The Vatican is the supreme authority as far as the approval of a regional mass rite is concerned and in the ancient Church, a rite had to prove its antiquity up to two hundred years to be recognized by the Vatican (Pecklers 2009: 20). It is worth mentioning that the Vatican hardly ever gave approval to a vernacular translation of the Missal, if it deviated from the Latin source texts both in terms of content and form. While other dioceses around the world are denied their own versions of the Missale Romanum by the Vatican, the African dioceses were given a great deal of autonomy in adapting the Roman Rite and this is particularly true in the case of the Zaire usage.

But why deviate from the traditional Roman Rite when the Church stood for uniformity and staunch fidelity to the Latin 
source texts? Why were texts like the Zaire usage approved, even when translations of the Missale Romanum sent by dioceses around the world were rejected by the Vatican? The reason is that Zaire being one of the "mission lands" newly converted to Catholicism, was given a certain degree of autonomy to include cultural elements unlike other regions, like Kerala where Catholicism had been in practice for long. Cultural elements could not be avoided completely; traces of it still pervaded in the minds of the converts. Thus, the official book which contained the prayers of the Roman Rite viz. the Missale Romanum was customized to suit the tastes of the Catholics in Africa, especially in dioceses ${ }^{18}$ like Zaire, following the policy of enculturation of the Second Vatican Council.

\section{Cultural Adaptations in the Translation of the Zaire Usage}

It is significant to note that various cultural elements have shaped the way in which the Zaire Usage was translated and structured. These elements are quite different and highly dependent on the cultural heritage of Zaire. There are three areas where the structure of the translation was modified- the role of the announcer, invocation of the ancestors and the order of the sign of peace and penitential rite.

The importance and role of the announcer ${ }^{19}$ in the Zaire Usage translation is a significant point of modification. The entry of the announcer signifies the beginning of the Mass and he/she is like a herald who briefs the community about the Mass. The announcer uses a special way of greeting, which creates a sense of bonding among the members of the community and is also for responsible for introducing the celebrant. The words of

\footnotetext{
${ }^{18}$ Basic regional unit of the Catholic Church under a bishop.

${ }^{19}$ Such a figure is absent in other vernacular translations of the (English) Roman Missal or the (Latin) Missale Romanum.
} 
the announcer are not impromptu, but scripted as these words should create a kind of spiritual awakening in the fraternity. The readings for the day are also introduced by the announcer and he/she "intervenes before the Eucharistic Prayer in the dialogue" (Chase 2013: 32). However, the announcer of the Zaire Usage cannot be compared to people giving announcements at the beginning of the Mass in the traditional Missale Romanum.

Next, the Zaire Usage translation gives a great deal of importance to invoking the saints and ancestors while the traditional Missale Romanum does not give much importance to calling on ancestors, except on special occasions like Masses for the dead. It reflects the height of enculturation and is the most discussed aspect of the Zaire Usage translation. This part of the translation reflects the Zairean concept of ancestors:

Ancestors are the wise, brave and old parents (men and women) who in the time of their human existence have brought honour to their families and descendants. They are honoured, venerated, commemorated and invoked as intermediaries for approaching the divine domain (Egbulem 1991: 59).

Similar to the Catholic concept of saints, the Africans venerate their ancestors who have lived a life worthy of imitation and hence they are given a central role in the celebration of the Mass. Traditionalists may argue that this stand taken in the translation may subjugate the role of Christ, who is regarded as the sole source of "salvation" (Lumbala 1998: 48). However, it was not considered necessary to name these ancestors and hence the invocation takes a general tone: "And you our righteous ancestors/ Be with us" (Chase 2013: 32). They serve as a kind of intermediary between the community and the 
divine, all the while reminded that the intercession to these ancestors are only secondary to that made to Christ.

The penitential rite and the sign of peace are placed at a different point in the Zaire Usage translation; the sign of peace follows the penitential rite which is placed after the Liturgy of the Word ${ }^{20}$. This is deemed effective as the people offer each other the sign of peace after repenting over their sins and purging their heart and it is said to be adapted from the Didache $^{21}$ (Egbuleim 1991: 63).

Kangas describes how the celebrants and acolytes dance around the altar as a sign of reverence during Mass (2013). According to Zairean culture, dancing was done from time immemorial for all occasions: "People have danced at deaths, initiations, marriages, sacrificial prayers, healings, ancestral worship, before battles, and before the ritual ploughing of the first furrow in spring to mention only a few" (Wagner 1993: 127). Body postures are more or less restricted to standing, bowing, kneeling and sitting according to the instructions given in the traditional translation of the Roman Missal. The Roman Missal is often accused of being centred on western traditions and African scholars have often problematized the issue of its regional versions' failure to mirror its cultural nuances. Dance and local music traditions being integral to their culture thus finds its place in their liturgical rites, whereas such aspects would be considered unacceptable and inappropriate in other oriental cultures, say for example, in a diocese in Kerala. The General Instructions of the Roman Missal specifically instructs on how the lay people "should" stand during the Entrance Procession and the Gospel, whereas the Zaire Usage translation instructs the people to dance in

\footnotetext{
${ }^{20}$ Refer 2.

${ }^{21}$ Ancient text dating back to the first century also known as The Teaching of the Twelve Apostles.
} 
their places during the Entrance Procession and to sit during the reading of the Gospel. The Zaire Usage translation is thus a culture-specific praxis of what the policy of enculturation envisaged.

The priest would wear robes which are typically worn by a clan chief in Congo and the (male) acolytes carry spears (Kangas 2013). This is in stark contrast to the embellished robes which the instruction in the original translation specifically insists upon. Spears are also typical of the tribal tradition of Zaire whereas classical tradition instructs altar boys to carry a crucifix or a burning lamp. By including such instructions in the translation and it [the translation] getting the Vatican's stamp of approval was nothing short of a significant paradigm shift in the perspective of the Catholic Church in the 1980s.

\section{Conclusion}

Translations of the Missale Romanum continue to be made to this day with the Vatican stressing that its structure and most importantly the words remain as close as possible to the Latin source texts and here, the Zaire Usage remains an 'anomaly' among all the translations which have come till date. As to whether the adaptations made in the translations were extreme or not, the debate is still on. Some feel that these changes have gone to a great extreme, while some others feel that the Mass has not been "enculturated" enough. Including body movements like dance into the Mass have even sparked interesting debates on the philosophical 'Mind-Body Problem' with scholars debating on how the West is concerned only about the mind while Africa at the other end of the binary stressing on body and its movements which can also be interpreted as a means of worship. The peculiar culture of Zaire has resulted in this new Missal and Vatican has deviated great deal from its Post-Conciliar reforms in granting 
recognition (recognition) to The Roman Missal for the Dioceses of Zaire. However, the formation of such a divergent canon is not possible in today's ecclesiastical climate which is why Chase calls the Zaire Usage as the "special product of post-conciliar creativity and compromise" (2013: 28).

\section{References}

BARRETT, TONY. 1978. Incarnating the Church in Turkana. Eldoret: Gaba Publications.

Chase, Nathan Peter. 2013. A History and Analysis of the Missel Romain pour les Dioceses du Zaire. Obsculta 6. 2836

Chima, AleX. 1984. Africanising the Liturgy - Where are We Twenty Years After Vatican II! AFER 25. 282-89.

EgBulem, Chris NwAKA. 1991. The Genius and Typology of African Prayers. Proceedings of the North American Academy of Liturgy. North American Academy of Liturgy.

Foster, Marc Ashley. 2005. Missa Luba: A New Edition and Conductor's Analysis. University of North Carolina. 1-6.

Gibellini, Rosino. 1994. Paths of African Theology. New York: Orbis Books.

Theology of InCUlturation. In New Catholic Encyclopedia. 2003. Online: www.encyclopedia.com/ religion/encyclopedias-almanacs-transcripts-andmaps/inculturation-theology.Accessed on 7 Oct. 2018. KangAS, BILly. Jan 2013. The Roman Missal for the Dioceses of Zaire. Patheos $1 . \quad$ Online: www.patheos.com/blogs/billykangas/2013/01/the-romanmissal-for-dioceses-of-zaire.html

LOnG, Lynne. 2013. The Translation of Sacred Texts. In Carmen Milán and Francesca Bartrina (eds.), The Routledge Handbook of Translation Studies. London: Routledge. 46474. 
Rewriting Cultural Paradigms:...

Lumbala, FRAnÇOIS. 1998. Celebrating Jesus Christ in Africa: Liturgy and Inculturation. New York: Orbis.

PAUL, VI. 1963. Sacrosanctum Concilium. Vatican Archives. 4 December, 1963.

Online: www.vatican.va/archive/hist_councils/ii_vatican_council/d ocuments/vat-ii_const_19631204_sacrosanctumconcilium_en.html. Accessed on 12 Nov. 2016

PECKLERS, KeITH. 2009. The Genius of the Roman Rite: The Reception an Implementation of the Roman Rite. London: Burns \& Oates.

SANON, ANSELME. 1983. Cultural Rooting of the Liturgy in Africa since Vatican II. Liturgy: A Creative Tradition. New York: Seabury Press. 63-64.

TOWNSEND, CHRIS. 2016. Let's Talk Language- the English Translation of the Mass. The Jesuit Institute of South Africa. $7 \quad$ June 2016.2 Online: www.jesuitinstitute.org.za/index.php/2016/06/07/lets-talklanguage-the-english-translation-of-the-mass/

Wagner, Mary Anthony. 1993. The Sacred World of the Christian: Sensed in Faith. Minnesota: Liturgical Press. 